\title{
Distribution of Arsenic with Iron, Manganese and Copper in Borehole Sediments of the River Tista and Jamuna
}

\author{
Mohammad Arifur Rahman, Md. Jahangir Alam, Nur-E-Alam Siddique and A. M. Shafiqul Alam* \\ Department of Chemistry, Dhaka University, Dhaka-1000, Bangladesh
}

(Received : 30 May 2012; Accepted : 19 February 2013)

\begin{abstract}
Boreholes sediments (1-6 m depth) of the river Tista and Jamuna in Bangladesh were collected for the analysis of As, Fe, Mn, Cu and organic carbon. Chemical analysis reveals that $\mathrm{Mn}$ and Fe hydroxides and organic matter are the major leachable solids which carrying As. High levels of arsenic concentration in aquifers are associated with fine grained sediments at the lower depth of the sediment layer. The highest As containing sediment was gray and texture of sediment was clay type. The colour of the least As containing sediment was white and texture of sediment was sandy. In addition, this study indicate that As is closely associated with Fe and slightly correlated with Mn and $\mathrm{Cu}$ in the sediment of the river Tista and Jamuna. Arsenic was distributed regularly in sediments with $\mathrm{Fe}, \mathrm{Mn}, \mathrm{Cu}$ and organic matter from upper stream to lower stream of Tista and Jamuna river belt in Bangladesh.
\end{abstract}

Key words: Arsenic, sediments, Tista, Jamuna, Iron, manganese, copper.

\section{Introduction}

Arsenic contamination of groundwater in large areas of Bangladesh and West Bengal, India has received much attention and is considered as one of the worst environmental disasters in the world ${ }^{1-2}$. Arsenic is widely distributed as a trace constituent in rocks and weathered soils. In Chapai-Nawabganj, Northwestern Bangladesh, arsenic may be derived from the weathering of rocks exposed along the Himalayan orogenic belt, or oxidation of metal sulfides ${ }^{3}$. However, the poor correlation between dissolved sulfate and arsenic in the groundwater of Bangladesh argues against metal sulfides as the main source of As ${ }^{4}$. Released of arsenic is strongly sorbed by stream sediments and Fe oxides under aerobic conditions when it is transported by surface water ${ }^{5}$. As-sorbed sediments are then deposited with organic matter in alluvial settings. The process of As mobilization in alluvial sediments is complex, it may occur as $\mathrm{Fe}$ and $\mathrm{Mn}$ oxides are reductively reduced by $\mathrm{Fe}(\mathrm{III})$-reducing bacteria under moderately reducing conditions ${ }^{6}$. Alternatively, arsenic may be mobilized by ionic competition of other ions (e.g., nitrate, carbonate, and silicate) on sorbing sites of oxides ${ }^{7}$. Thus the fate and mobility of arsenic is dependent on the biogeochemical transformations and desorption that occur in the sediments ${ }^{8}$.

Previously we have reported the mobilization of arsenic with iron, manganese and copper in borehole sediments of the river Padma and Jamuna ${ }^{9-10}$. In this study, large amount of $\mathrm{Fe}$ has been obtained, which has endorsed the assumptions of the relations of As with Fe. The small correlation value in case of As, Fe and Mn indicates that not all the minerals of arsenic and Mn but only hydroxides of Fe and $\mathrm{Mn}$ interfere with As. The river Tista is connected with the river Jamuna. Therefore, it is necessary to find out the distribution and the correlation of arsenic along with iron, manganese and copper in the river sediment of Tista and Jamuna.

The objective of this work is to see level of arsenic from upstream to downstream at different locations of the river Tista and Jamuna in Bangladesh such as Lalmonirhat, Kurigram, Gaibandha and Tangail. The focal theme of this research is that the sediments with high arsenic content can

\footnotetext{
*Author for Correspondence, e-mail: amsalam2010@gmail.com
}

play an important role in the ground water quality and consequently it also influences the concentration of the trace metals in both the water column and biota, if they are desorbed or become available to benthic organisms. The specific objective of the work is to find out the distribution of As along with $\mathrm{Fe}, \mathrm{Mn}$, and $\mathrm{Cu}$ on sediments.

\section{Experimental}

\section{Sampling locations}

Four locations were selected as sampling sites at entering point (upstream) and end point (downstream) of the river Tista and Jamuna in Bangladesh. The sampling locations are presented in Fig. 1. Sampling locations are: Lalmonirhat, Kurigram of Jamuna River and gaibandha and Tangail of Tista River. All the sediment samples were collected at several depths ranging from 1 to 6 meters using 1.5 inches (diameter) pipe through normal digging procedure. These were taken in plastic bottles and sealed with tapes and then taken to the laboratory for further analysis.

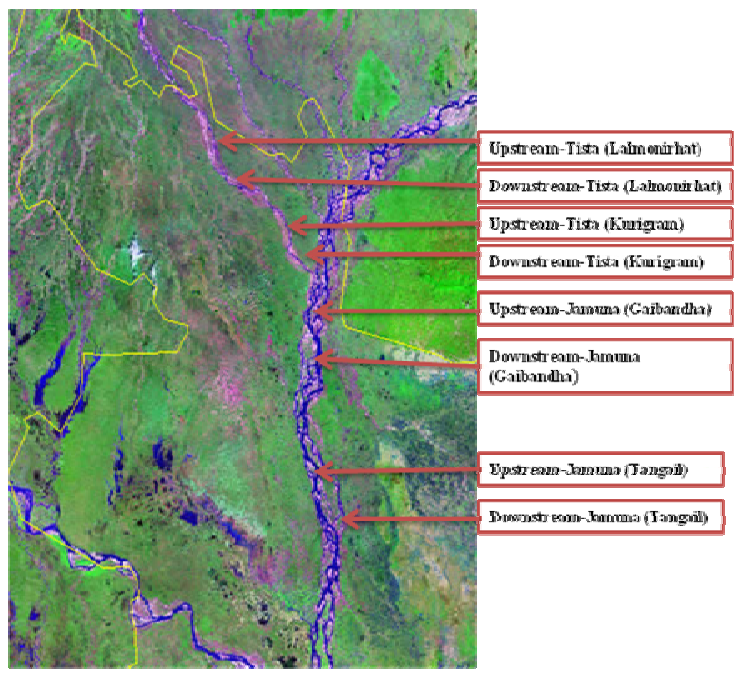

Fig. 1. Different sampling locations along the river Tista and Jamuna. 


\section{Digestion procedure of sediments}

The sediment samples were digested following the $\mathrm{HNO}_{3}$ and $\mathrm{HClO}_{4}$ Digestion method ${ }^{9}$. Both the acids were analytical reagent grade. Accurately weighed amount (0.1g) of the sample was taken in a Teflon acid bomb. $3.0 \mathrm{ml}$ of nitric acid and $2.0 \mathrm{~mL}$ of perchloric acid were added to the sample. Then the acid bomb was placed in an oven for heating at $200{ }^{\circ} \mathrm{C}$ for two hours. After digestion, the sample was cooled, filtered and transferred to a $25.0 \mathrm{~mL}$ volumetric flask. The solution was then made up to the mark with the help of distilled deionized water. The sample solutions were then transferred in plastic bottles and preserved in freeze at $4{ }^{\circ} \mathrm{C}$.

\section{Chemical analysis}

Arsenic was analyzed using Hydride Vapor Generator (HVG-1, Shimadzu, Japan) attached with Atomic Absorption Spectrophotometer (AAS-680, Shimadzu, Japan.). The total arsenic content was determined from the generated arsine gas $\left(\mathrm{AsH}_{3}\right) . \mathrm{Fe}, \mathrm{Mn}$ and $\mathrm{Cu}$ were analyzed using flame Atomic Absorption spectrophotometer (AAS-680, Shimadzu, Japan) using air-acetylene flame. All reagents and chemicals were of analytical grade. Preparation of reagents was made with de-ionized water. The analytical methods were checked analyzing SRM (Standard reference materials No 404F9229 KANTO CHEMICAL INC. Cho$\mathrm{ku}$, Tokyo Japan). The certified values were varied from 2 to $5 \%$. The interferences of the matrix in the digested sediments were also checked with the addition of standard addition method. Very little interferences were observed (3$5.5 \%$ ) during the analysis.

Total organic carbon (TOC) contents of the sediment samples were measured by a dry combustion method using the furnace (model, ABF, Carbolite, UK). The dried sample powders ( $0.5 \mathrm{~g})$ were put into a screw-top glass vial (1.6 $\mathrm{cm}^{3}$ ), which was heated at $450{ }^{\circ} \mathrm{C}$ for $3 \mathrm{~h}$ to remove the organic contaminants and then weighed. About $1 \mathrm{~mL}$ of $1 \mathrm{~N}$ $\mathrm{HCl}$ was added to decompose carbonate. The sealed vial was put into an oven at $50{ }^{\circ} \mathrm{C}$ overnight, because some carbonate solids such as dolomite were not easily dissolved in $\mathrm{HCl}$. After cooling at room temperature, a few drops of 6 $\mathrm{N} \mathrm{HCl}$ was added to check if carbonates had been completely digested. The sample was put in desiccators with $\mathrm{NaOH}$ pellets (as desiccant and to trap excess $\mathrm{HCl}$ ) and dried for two weeks. After drying, TOC was determined in the sediments samples ${ }^{11}$.

\section{Results and Discussion}

Physical and chemical properties of the sediment samples

Characteristics colour and particles size of sediments from surface layer to depth of $6 \mathrm{~m}$ reveal the lithographic variations. Lalmonirhat \& Kurigram situated on the Tista alluvial fan of northwest Bengal basin which is bounded by the Himalayan Frontal Thrust towards the north. The fan has developed by sediments carried by rivers, originating from the Himalayas, and draining the Siwalik for deep. Alluvial sediments grade from coarser at the north to finer at the south. In the collected Samples it was observed that the stratigraphic sequence consists of Clay or silt at top, passing down ward into light to coarse sand or sandy silt.
The uppermost layers in most cases consist of reddish, yellowish or off white clay or Silt.

Table 1. Average physical and chemical properties of sediment samples of the Jamuna and Tista Rivers.

\begin{tabular}{ccccc}
\hline $\begin{array}{c}\text { Depth } \\
(\mathbf{c m})\end{array}$ & $\begin{array}{c}\text { Type of } \\
\text { sediment }\end{array}$ & Colour & $\mathbf{p H}$ & $\begin{array}{c}\text { Organic } \\
\text { Carbon } \\
\text { (g/Kg) }\end{array}$ \\
\hline 1 & Sand & White & 6.60 & 0.38 \\
2 & Clay & Yellow & 6.78 & 0.42 \\
3 & Sand & White & 7.71 & 0.68 \\
4 & Sand & White & 7.94 & 1.22 \\
5 & Silt & Yellow & 6.61 & 2.55 \\
6 & Silt & Reddish & 7.05 & 3.48 \\
\hline
\end{tabular}

The other two sampling locations - Gaibandha and Tangail are situated on Brahmaputra flood plain zone. Soil and sediments of this geomorphic unit are yellowish to reddish or grayish in most proportion which indicate the presence of iron, manganese as their oxidized form. These oxided especially Fe-and Mn-oxyhydroxide minerals strongly absorb arsenic, while gray sediments may contain abundant organic matter which usually host As rich groundwater under reducing conditions. The average type of sediments in the sampling area is presented in Fig. 1.

The fine-grained sediments are relatively rich in organic matter. The content of total organic carbon varied between 0.528 and $3.48 \mathrm{~g} \mathrm{Kg}^{-1}$ in sediments.

Variation of $\mathrm{Fe}, \mathrm{Mn}$, and $\mathrm{Cu}$ with As in different region of the Tista and Jamuna River

Arsenic concentration was found to be varied from upper and downstream of every sampling location as presented in Fig. 2, Fig. 3 and Fig. 4 due to geochemical, biogeochemical transformation and geophysical aspect of sediments, rocks and different ores present in soil. In most cases, As concentration was found to be lower in the downstream region than the upper stream of the Tista-Jamuna River belt.

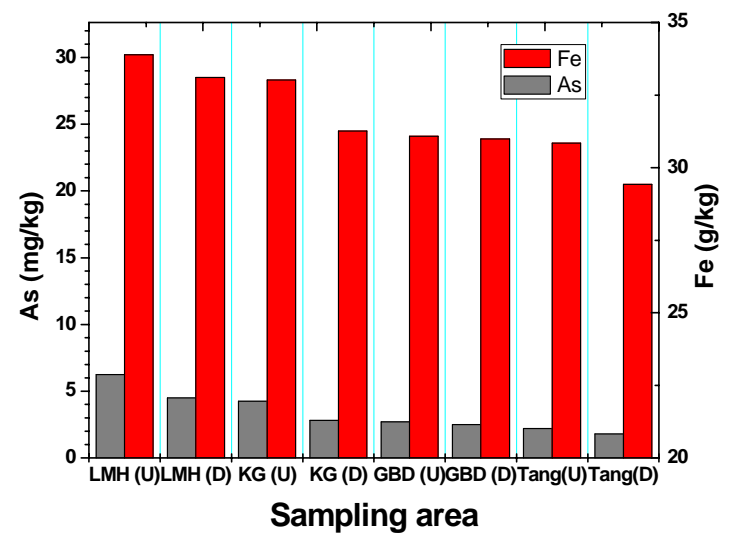

Fig. 2. Variation of As and Fe in different sampling sites along Tista- Jamuna rivers Belt. U: Upstream; D: Downstream; LMH: Lalmonirhat; KG: Kurigram; GBD: Gaibandha; Tang: Tangail; Lalmonirhat and Kurigram (Tista River); Gaibanda and Tangail (Jamuna River) 
Distributions of major and trace elements in sediments are mainly controlled by a variety of factors including sediment texture, source-rock mineralogy, and geochemical processes 12. Fine-grained clays are enriched in trace metals, as they possess higher surface areas than coarser grains $\mathrm{do}^{13}$. Factors controlling the spatial sediment composition can be broadly considered in terms of source effects, processes that occur during transport and deposition, and post-depositional processes ${ }^{14}$.

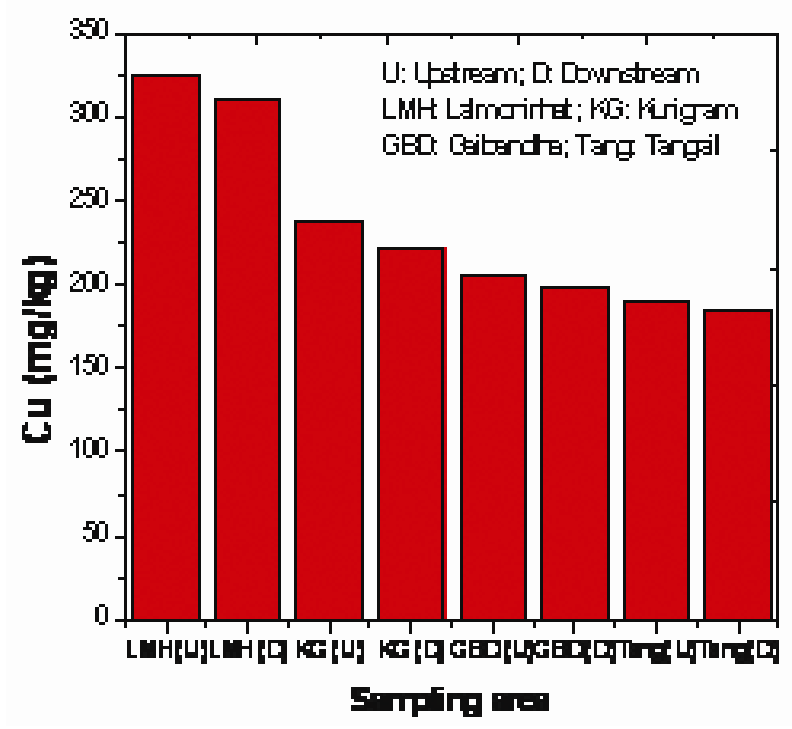

Fig. 3. Variation of $\mathrm{Cu}$ in different sampling sites along TistaJamuna Rivers Belt. Lalmonirhat and Kurigram (Tista River); Gaibanda and Tangail (Jamuna River)

The distributions of As in the sediments are similar to those of Fe, $\mathrm{Cu}$ and $\mathrm{Mn}$ (Fig. 2, Fig. 3, and Fig. 4) and As is only shown in Fig. 2, suggesting that As is strongly sorbed by Febearing minerals such as Fe oxyhydroxides. It is notable that among these three metals (Fe, $\mathrm{Cu}$ and $\mathrm{Mn}$ ), Fe content was the highest in the sediments indicating the significant relationship were between the sources of arsenic and Fe. However $\mathrm{Cu}$ and $\mathrm{Mn}$ content was lower compare to $\mathrm{Fe}$ in the sediments indicating the poor relation of $\mathrm{Cu}$ and $\mathrm{Mn}$ with As. Relatively high Fe/As and low $\mathrm{Mn} / \mathrm{As}, \mathrm{Cu} / \mathrm{As}$ ratio were found in the borehole sediments. This is because the presence of more soluble Fe-oxides and hydroxides rather than insoluble Fe-silicate in the borehole sediments of the river Tista and Jamuna. In addition, there may be due to the transportation of $\mathrm{Cu}$ and $\mathrm{Mn}$ from the water stream to sediments, being rapidly remobilized from the solids and $\mathrm{Cu}$ and $\mathrm{Mn}$ are then transferred back to the water stream.

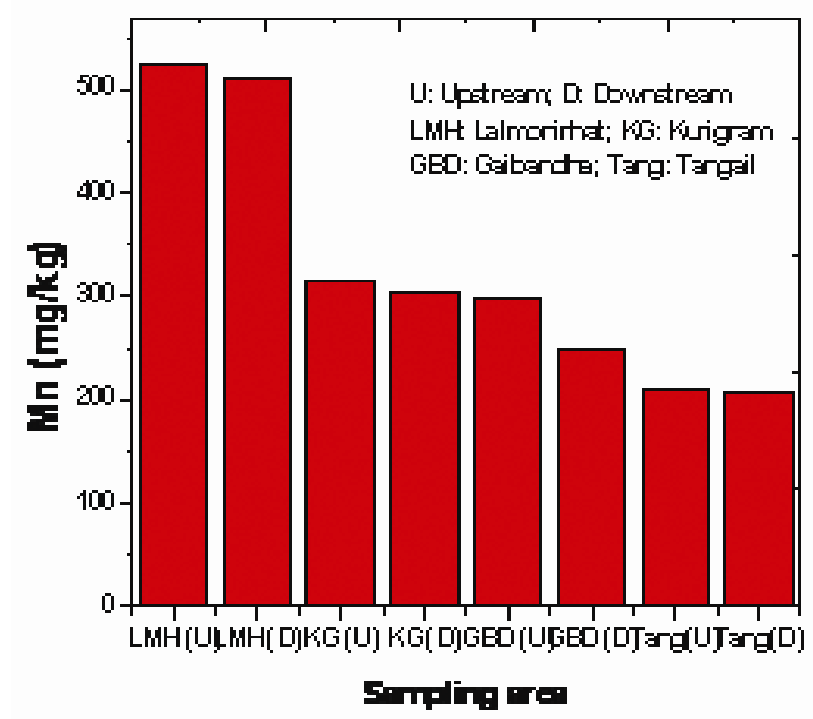

Fig. 4. Variation of $\mathrm{Mn}$ in different sampling sites along TistaJamuna Rivers Belt. Lalmonirhat and Kurigram (Tista River); Gaibanda and Tangail (Jamuna River)

Distribution of As in various types of coloured sediments in the Tista-Jamuna River

The average distribution of arsenic in different colored and types of sediments samples collected from the Tista-Jamuna River belt is presented in Fig. 5. The colour of the highest As containing sediment was gray and texture of sediment was clay type. These two physical parameters indicate the organic or manganese scavengers of As in anaerobic or poorly aerated reducing condition at this ground level. The colour of lowest As containing sediment was white and texture of sediment was sandy. This type of sediment may contain iron which is reduced in form.

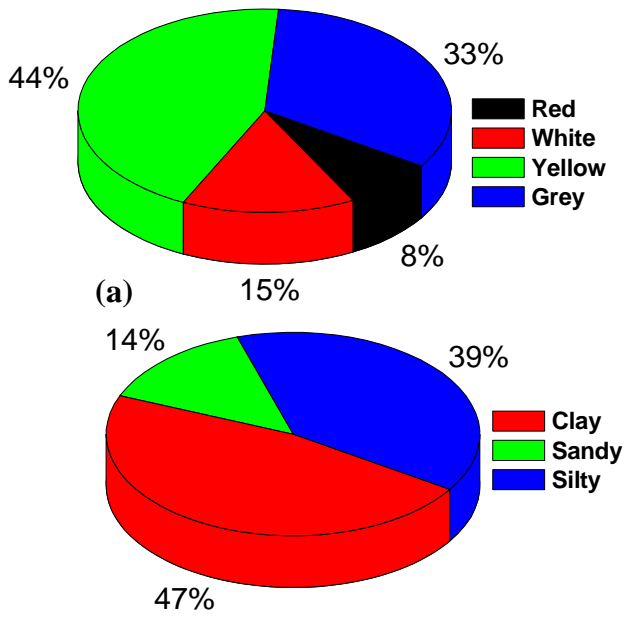

(b)

Fig. 5. Distribution of As in different (a) colored (b) types of sediments in sampling sites

Greater fraction of arsenic was found in Clay and gray colored sediment. Yellowish colour of sediment indicates the presence of iron oxy hydroxide (FeOOH -Goethite) and grayish color might be for manganese oxyhydroxide (MnOOH-Groutite). Both the iron and manganese were found in high amount using atomic 
absorption spectrometry. Arsenic is found in yellow and grayish sediment in high percentages. Therefore, both iron oxy hydroxide and manganese oxyhydroxide are two main sources for being Scavenge of arsenic in sediment. Arsenic adsorbed or coprecipitates with these scavengers and contaminates the adherent sediments.

\section{Factors controlling arsenic distribution in sediment}

The average concentration of arsenic and organic carbon in sediments of Lalmonirhar (Tista River) is presented in Fig.6. It is observed that there is a correlation between arsenic and total organic carbon of sediment samples in the river Tista. Similar correlation was observed in the sediments of the river Jamuna in our previous work ${ }^{10}$. This correlation suggests that the organic carbon in sediment plays a very important role on arsenic distribution in different sediment samples along the river Tisata and Jamuna belt. The distribution of As in the subsurface sediments is not solely controlled by a single mineral phase ${ }^{15}$. Fine-grained sediments, As-sorbed Fe oxyhydroxides, and natural organic matter were deposited together in low lying areas in the alluvial plain, leading to the local As enrichment in sediments. It is also likely that the co-existence of Fe (oxy) hydroxides, As and organic matter is caused by the strong adsorption affinity of metal hydroxides for both As and organic matter in the finer sediments 16

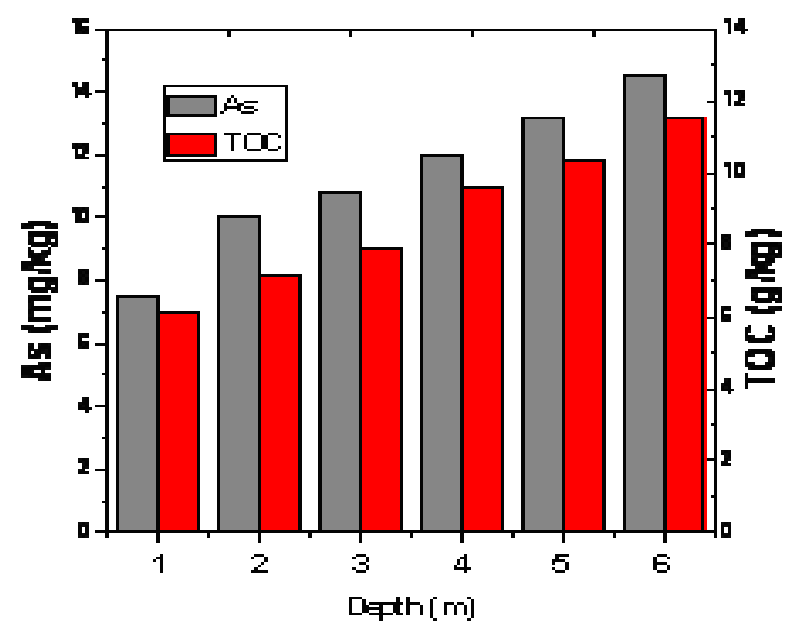

Fig. 6. Relationship of As with TOC in sediment on the river Tista at upstream and downstream.

Positive correlation of As and Fe was observed in the sediments of Tista river which is consistent with the previous reports by Alam et. al ${ }^{9-10}$ for the sediments of padma and Jamuna river of Bangladesh. This study indicate that there are strong correlations among $\mathrm{As}, \mathrm{Fe}$ and $\mathrm{Mn}$ in sediments which are consistent with the mobilization of arsenic from upstream to downstream in the Tista and Jamuna river sediments.

\section{Conclusions}

It can be concluded that arsenic was distributed from one location to another and as a result the variation in arsenic content was found in different locations. The study suggests that the distribution of arsenic in the sediments is not only controlled by single mineral phase, but arsenic may be partitioned into four phases: metal (Fe, $\mathrm{Mn}$ and $\mathrm{Cu}$ ) hydroxides, Fe sulfides, and also organic matter. Arsenic is correlated to Fe whereas it is slightly correlated with $\mathrm{Mn}$ and $\mathrm{Cu}$.

\section{References}

1. Mukherjee, A. B., P. Bhattacharya, 2001. Arsenic in groundwater in the Bengal Delta Plain: slow poisoning in Bangladesh. Environ. Rev., 9, 189-220.

2. Ahmed, K. M., P. Bhattacharya, M. A. Hasan, S. H. Akhter, S. M. M. Alam, M. A. H. Bhuyian, M. B. Imam, A. A. Khan, O. Sracek, 2004. Arsenic enrichment in groundwater of the alluvial aquifers in Bangladesh: an overview, Appl. Geochem 19, 181-200.

3. Nickson, R.T., McArthur, J.M., Ravenscroft, P., Burgess, W.G., Ahmed, K.M., 2000. Mechanism of arsenic release to groundwater, Bangladesh and West Bengal, Appl. Geochem, 15, 403-413.

4. McArthur, J. M., P. Ravencroft, S. Safiullah, M. F. Thirlwall, 2001. Arsenic in groundwater: testing pollution mechanism for sedimentary aquifers in Bangladesh. Water Resour. Res., 37, 109-117.

5. Polizzotto, M. L., B. D. Kocar, S.G. Benner, M. Sampson, S. Fendorf, 2008. Near-surface wetland sediments as a source of arsenic release to ground water in Asia. Nature, 454, 505-508.

6. Peltier, E. F., S. M. Webb, J. F. Gaillard, 2003. Zinc and lead sequestration in an impacted wetland system. Adv. Environ. Res., 8, 103-112.

7. Ishiga, H., T. Nakamura, Y. Sampei, T. Tokuoka, K. Takayasu, 2000. Geochemical implication for the maximum flooding of the Jomon transgression in the coastal lagoon sediments, San'in district, SW Japan. Geosci. Rep. Shimane Univ. Jpn., 17, 11-20.

8. Akai, J., K. Izumi, H. Fukuhara, H. Masuda, S. Nakano, T. Yoshimura, H. Ohfuji, H. M. Anawar, K. Akai. 2004. Mineralogical and geomicrobiological investigations on groundwater arsenic enrichment in Bangladesh, Appl. Geochem, , 19, 215-230.

9. Sarifuzzaman, M., M. N. A. Siddique, F. K. Ferdousi, E. Ahmed, A. M. S. S. M. Alam, Ullah, 2007. Studies of arsenic mobilization with iron, manganese and copper in borehole sediments of the river padma. Pak. J. Anal. Environ. Chem., 8(1), 91.

10. Rahman, M. A., M. Mahmudul Hasan, Nur-E-Alam Siddique, A. M. Shafiqul Alam, 2011. Mobilization of arsenic with iron, manganese and copper in borehole sediments of the river Jamuna, J. Bangladesh Chem. Soci., 25(1), 30-37, 2011.

11. Reza, A. H. M. S. , J. -S. Jean, H. -J. Yang, M. -K. Lee, B. Woodall, C. -C. Liu, J. -F. Lee, S. -D, 2010. Luo, Occurance of arsenic in core sediments and groundwater in Chapai-Nawabhanj district, northwestern Bangladesh, Water Res., 44, 2021.

12. Abraham, J., 1998. Spatial distribution of major and trace elements in shallow reservoir sediments: an example from Lake Waco. Texas. Environ. Geol., 36 (3-4), 349-363.

13. Singh, M., M. Sharma, H. J. Tobschall, 2005, Weathering of the Ganga alluvial plain, northern India: implications from fluvial geochemistry of the Gomati River, Appl. Geochem, 20, 1-21.

14. Norman, M. D., P. De Deckker, 1990. Trace metals in lacustrine and marin sediments: a case study from the Gulf of Carpentaria, northern Australia. Chem. Geol., 82, 290-318.

15. Anawar, H. M., K. Komaki, J. Akai, J. Takada, T. Ishizuka, T. Takahashi, T. Yoshioka, K. Kato, 2002, Diagenetic control on arsenic partitioning in sediments of the Meghna River delta, Bangladesh. Environ. Geol., 41, 816-825.

16. P. L. Smedley, D. G. Kinniburgh, 2002. A review of the source, behavior and distribution of arsenic in natural waters. Appl. Geochem, 17, 517-568. 